\title{
ВАЖЛИВІСТЬ ЗНАННЯ АНГЛІЙСЬКОЇ МОВИ ДЛЯ ФАХІВЦЯ
}

\author{
КУЗІВ Ірина-Марія Іванівна - студентка 3-го курсу Дрогобицького \\ фахового коледжу нафти і газу, студентка 1-го курсу Дрогобицького державного \\ педагогічного університету імені Івана Франка \\ ПІЦь Леся Степанівна - викладач англійської мови Дрогобицького \\ фахового коледжу нафти і газу
}

DOI 10.32782/EP.2021.2.29

Съогодні першочерговим завданням вищої професійної освіти, яке поставили перед нею відносини ринкової економіки, що стрімко розвиваються, $\varepsilon$ підготовка конкурентоспроможного фахівия, здатного орієнтуватися в стрімкому поточі наукової $i$ технічної інбормачиї. Конкурентоспроможність сучасного ббахівия визначається не тільки його високою кваліфікаиією у профбесійній сфері, а й готовністю вирішувати професійні завдання в умовах іншомовної комунікаиї.

Знати англійсъку мову съогодні абсолютно необхідно для кожної освіченої людини $і$ хорошого бахівия.

Особливо важлива англійсъка мова для ефбективної роботи бізнесу, оскільки багато украйнсъких бірм співпрацюють з іноземними партнерами.

Ключові слова: іноземна мова, засоби комунікациі, освіта, побудова кар'єри, пробесійна діяльність, компетениія, технологія навчання

Постановка проблеми

Сьогодні першочерговим завданням вищої професійної освіти, яке поставили перед нею відносини ринкової економіки, що стрімко розвиваються, є підготовка конкурентоспроможного фахівця, здатного орієнтуватися в стрімкому потоці наукової і технічної інформації. Конкурентоспроможність сучасного фахівця визначається не тільки його високою кваліфікацією у професійній сфері, а й готовністю вирішувати професійні завдання в умовах іншомовної комунікації.

\section{Аналіз дослідження}

Аналіз зарубіжних і українських джерел показав, що сьогодні не існує загальновизнаного визначення терміна «компетенція». Поряд 3 цим виникає ідея фактора конкурентоспроможності або папки індивідуальних досягнень сучасного фахівця, що стає все більш популярним у нашій країні останнім часом. На Заході його називають портфоліо і говорять про нього як про один 3 основних освітніх трендів останнього десятиліття. Більше того, стверджується, що освіта XXI століття - це «школа портфоліо» і ідея портфоліо, або фактора конкурентоспроможності, виступає як один з істотних елементів модернізації освіти, що відбувається по всьому світу. У нашій країні, кажучи про папку або портфелі особистості, частіше за все мають на увазі простий збір усіх досягнень цієї особистості і новий спосіб їх оцінки. У цей час під впливом загальносвітових інтеграційних процесів виникла необхідність розвитку у майбутніх фахівців таких якостей, як ініціативність, підприємливість, професійна мобільність, вміння адаптуватися до умов, що змінюються, здатність до міжкультурних контактів у соціальній і професійній сферах.

Чимало питань цієї проблеми висвітлено у працях відомих учених, з-поміж яких: Колесник Анастасія Олександрівна, Волкова Світлана Олександрівна, Горбина Марина Олександрівна, Супрунов Семен Свгенович. 


\section{Обговорення, дискусії, актуально}

Виклад основного матеріалу

Сучасні умови життя, вимоги до майбутнього спеціаліста, нові прийоми прийняття на роботу вимагають пошуку нових підходів до підготовки майбутнього фахівця. Володіння іноземною мовою стає необхідною якістю особистості. Науково-технічний прогрес, що призвів до інформаційного вибуху, зумовив залучення зростаючого числа фахівців до безпосереднього здійснення міжнародних науково-технічних відносин і розширення культурних і ділових контактів.

Спеціаліст повинен бути широко ерудований, володіти методологією наукової творчості, сучасними інформаційними технологіями добування нової інформації i можливістю їі обміну в професійній сфері як рідною, так і іноземною мовою.

Вивчення іноземної мови у ВНЗ розглядається як обов`язковий компонент професійної підготовки фахівця з вищою освітою. Сучасна концепція мовної освіти у ВН3 передбачає створення такої системи підготовки фахівця, яка дозволить йому легко адаптуватися до динамічно мінливих умов професійної діяльності, тобто націлена на професійно-орієнтоване навчання іноземної мови, що диктується особливостями майбутньої професії або спеціальності. Воно передбачає поєднання оволодіння професійноорієнтованої іноземної мови 3 розвитком якостей студентів, знанням культури країни мови, що вивчається і здобуттям спеціальних навичок, заснованих на професійних i лінгвістичних знаннях. Професійно-орієнтоване навчання іноземної мови визнається сьогодні пріоритетним напрямком в оновленні освіти.

3`явилася нагальна потреба по-новому поглянути на процес навчання взагалі і на навчання іноземної мови зокрема. Іншомовне спілкування стає істотним компонентом професійної діяльності фахівців. Аналіз педагогічних науково-методичних джерел показав, що існує безліч методичних напрямків і технологій навчання іноземної мови у немовних ВНЗ. У цей час ставиться завдання не тільки оволодіння навичками спілкування іноземною мовою, а й придбання спеціальних знань за фахом.
У зв язку з цим стандарт освіти вимагає урахування фахової специфіки при вивченні іноземної мови, його націленості на реалізацію завдань майбутньої професійної діяльності випускників. Наявність лінгвістичних знань дає можливість бути в курсі всього нового, що видається в професійній галузі, озброює досягненнями світової науки, сприяє використанню їх у практиці. Розвиток міжнародних відносин, взаємопроникнення культур, а також науковотехнічна співпраця диктують необхідність звернутися до проблеми формування комунікативних умінь. На сучасному етапі міжкультурний, науковий обмін та професійні контакти здатні здійснювати лише ті фахівці, які залучені до іншомовних культур. Формування комунікативної компетенції відбувається за допомогою вивчення іноземних мов у процесі ознайомлення 3 національними особливостями, історією, соціальними нормами поведінки країн, мови яких вивчаються, а також природою міжкультурних конфліктів і способами їх вирішення.

\section{Висновок}

Знати англійську мову сьогодні абсолютно необхідно для кожної освіченої людини і хорошого фахівця. Що ж стосується кар`єри людини, знайти престижну роботу без знання англійської мови ще можливо, але стає все складніше. Роботодавці вважають за краще приймати фахівців зі знанням англійської мови. Та й кар єрний ріст буде забезпечений, роботодавець завжди надасть перевагу фахівцеві, який володіє міжнародною мовою. Особливо важлива англійська мова для ефективної роботи бізнесу, оскільки багато українських фірм співпрацюють з іноземними партнерами.

\section{入ітература}

1. Байдурова $\lambda$. А., Шапошникова Т. В. Метод проектів під час навчання учнів двох іноземних мов // Іноземні мови в школі. -2002. - № 1. - C.5-11.

2. Бім I. А. Деякі актуальні проблеми сучасного навчання іноземних мов // Іноземні мови в школі. - 2001. - № 4 - С. 5-8. 


\section{SUMMARY}

Today, the primary task of higher professional education, which was set before it by the relations of a rapidly developing market economy, is to train a competitive specialist who is able to navigate in the rapid flow of scientific and technical information. The competitiveness of a modern specialist is determined not only by his high qualification in the professional sphere, but also by his readiness to solve professional problems in the conditions of foreign language communication.

Knowledge of English today is absolutely necessary for every educated person and a good specialist.

English is especially important for effective business, as many Ukrainian companies work with foreign partners.

Keywords: foreign language, means of communication, education, career-building, professional activity, competence, learning technology.

3. Вербицький А. А. Активне навчання у вищій школі: контекстний підхід: Метод. посібник. - М .: Вища. шк., 1991. - 207 с.

4. Супрунов С. С. Від міжкультурної комунікації до міжкультурного навчання // Актуальні проблеми загальної теорії мови, перекладу і методики викладання іноземних мов. Випуск 4. Збірник статей міжрегіональної 3 міжнародною участю інтернетконференції. - М .: РЕУ ім. Г. В. Плеханова, 2017.

5. Шадриков В. Д. Нова модель фахівця: інноваційна підготовка і компетентнісний підхід. , 2002.

6. Модернізація вищої школи: забезпечення якості професійного: Матеріали
Всеросійської науково-практичної конференції. Ч.2. - Барнаул: Изд-во ААЕП, 2004. $-108 \mathrm{c}$.

7. Харламов, I. Ф. Педагогіка: Уч. посібник для студ. по пед. спец. І. Ф. Харламов. 5-е изд. перераб. і доп. М .: Гардарики, 2005. $516 \mathrm{c}$.

\section{References}

1) Baidurova LA, Shaposhnikova TV Method of projects during the teaching of students of two foreign languages // Foreign languages at school. -2002. - № 1. - P.5-11.

2) Bim IL Some current problems of modern foreign language teaching // Foreign languages at school. - 2001. - № 4 - P. 5-8.

3) Verbytsky AA Active learning in higher education: a contextual approach: Method. manual. - M .: Higher. school, 1991. - 207 p.

4) Suprunov SE From intercultural communication to intercultural learning // Actual problems of general theory of language, translation and methods of teaching foreign languages. Issue 4 . Collection of articles of the interregional conference with international participation. M .: REU them. GV Plekhanov, 2017.

5) Shadrikov VD New model of the specialist: innovative training and competence approach., 2002.

6) Modernization of higher school: quality assurance: Proceedings of the All-Russian scientific-practical conference. Part 2. - Barnaul: Izd-vo AAEP, 2004. - 108 p.

7) Kharlamov, IF Pedagogy: Uch. manual for students. on ped. special IF Kharlamov. 5th ed. reworked. and ext. M .: Gardariki, 2005. $516 \mathrm{~s}$. 